Proc. Estonian Acad. Sci. Eng., 2003, 9, 4, 261-271

\title{
Elevated temperature wear of chromium carbide based cermets
}

\author{
Irina Hussainova and Maksim Antonov
}

Department of Materials Engineering, Tallinn Technical University, Ehitajate tee 5, 19086 Tallinn, Estonia; irhus@staff.ttu.ee

Received 7 July 2003, in revised form 28 October 2003

\begin{abstract}
Good thermomechanical properties, combined with low density and bulk chemical stability at temperatures approaching $1300^{\circ} \mathrm{C}$, make chromium carbide based composites of interest for a variety of wear-resistant applications and especially for applications at elevated temperatures. The purpose of this work is to study the erosion behaviour of $\mathrm{Cr}_{3} \mathrm{C}_{2}-\mathrm{Ni}$ cermets at room and elevated temperatures of 300 and $600{ }^{\circ} \mathrm{C}$. Systematic studies of the influence of the impact variables on the collision process have been carried out using silica particles. The erosion of ceramic-metal composites is associated with the combination of ductile and brittle modes of wear and material behaviour is influenced by both microstructure and test conditions. The high temperature oxidation behaviour of $\mathrm{Cr}_{3} \mathrm{C}_{2}$-Ni has been investigated to show the advantage of these materials over conventional cemented carbides at elevated temperatures.
\end{abstract}

Key words: erosion, composites, microstructure, high temperature wear, oxidation.

\section{INTRODUCTION}

Solid particle erosion is a serious problem in gas turbines, separators, valves, etc. However, few investigations have been carried out on the elevated temperature erosion of materials, despite the fact that ceramic - metal composites have many potential applications in such conditions. The cemented carbides WCCo are known for their high toughness but exhibit a low resistance to plastic deformation at high temperatures $\left[{ }^{1}\right]$. TiCN-Mo-Co cermets exhibit a high resistance to elastic and plastic deformation at elevated temperature but their brittleness limits their application $\left[{ }^{2}\right]$.

Refractory chromium carbide based materials have many desirable properties for applications at high temperature and in aggressive environments. The primarily covalent bonding, exhibited by carbides, provides many of the key 
properties required for advanced applications, including high stiffness and high specific strength at high temperature. Unfortunately, covalent bonding also makes these compounds brittle at ambient temperature. As a result, these materials have low damage tolerance. In addition, these materials can be difficult to produce with low porosity. Despite of limitations, refractory $\mathrm{Cr}_{3} \mathrm{C}_{2}-\mathrm{Ni}$ cermets may have application in environments where wear and corrosion resistance is required, especially if an effective means of enhancing their damage resistance can be found.

The addition of a ductile second phase is one of the methods that can be used to improve the toughness of carbides. In this way, a composite structure is created in which the wear and corrosion-resistant properties of the matrix carbides are combined with the enhanced toughness of the metallic phase. However, ductile phase toughening typically results in a drop in the hardness of the composites $\left[{ }^{3}\right]$, resulting in the classical trade-off between hardness and toughness. The wear of cermets is a direct function of both hardness and toughness, and the optimum wear behaviour is obtained when both these properties are maximized.

Recently there have been efforts to study the effect of solid particle erosion on ceramic-matrix composites $\left[^{4-6}\right]$. It is generally agreed that hard particle size and porosity as well as test conditions influence the abrasive and erosive wear rate $\left[{ }^{5-7}\right]$. The erosion of ceramic-metal composites is associated with the combination of ductile and brittle modes of wear and material behaviour is influenced by both microstructure and test conditions. A change in maximum wear rate is observed with increasing temperature, and this has been attributed to the transition between "brittle" and "ductile" behaviour $\left.{ }^{8,9}\right]$. The fact that an oxide scale can form at high temperature further complicates the analysis. The oxide layer, formed on the binder phase at low temperatures, may be removed through a brittle erosion mechanism $\left[{ }^{10}\right]$. However, at higher temperatures the oxide plasticity increases demonstrating that the erosion of cermets is a very complex phenomenon of competing tribo-corrosion processes, between the erosion and oxidation of the binder materials and the matrix.

This study was undertaken to examine the erosive wear behaviour of $\mathrm{Cr}_{3} \mathrm{C}_{2}-\mathrm{Ni}$ at room and elevated temperatures. All materials investigated were produced by conventional P/M technique. Cermets containing from 60 to $90 \% \mathrm{Cr}_{3} \mathrm{C}_{2}$ were studied to determine the effect of test variables and temperatures on the cermet wear behaviour.

\section{MATERIALS AND EXPERIMENTAL DETAILS}

The $\mathrm{Cr}_{3} \mathrm{C}_{2}$-Ni cermets were fabricated at Tallinn Technical University from $\mathrm{Cr}_{3} \mathrm{C}_{2}$ and Ni powders using a conventional $\mathrm{P} / \mathrm{M}$ technique $\left[{ }^{11}\right]$. To examine the microstructure, scanning electron microscope (SEM) was used. Micrographs of some cermets investigated are shown in Fig. 1. The porosity of specimens was up to $5 \%$. 


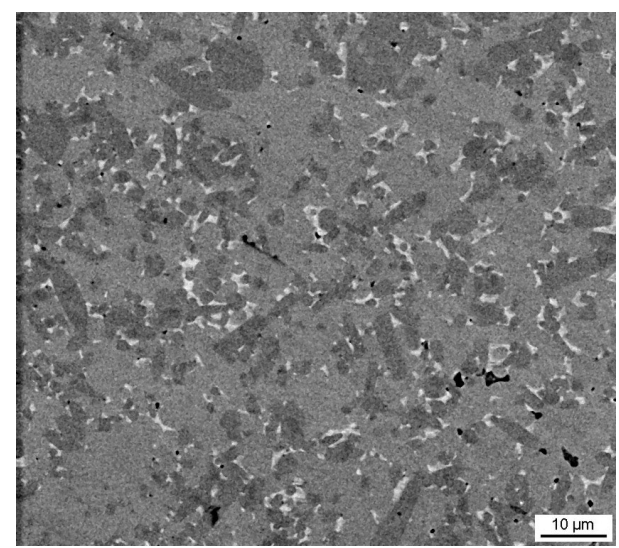

$\mathrm{C} 1$

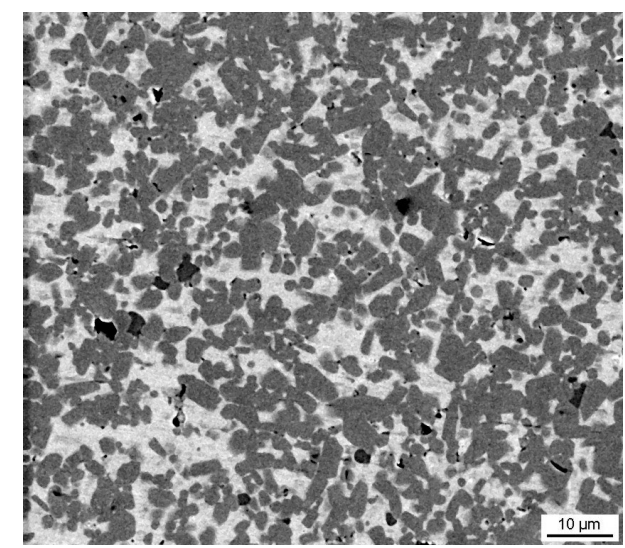

$\mathrm{C} 4$

Fig. 1. SEM micrograph of chromium carbide based cermets at room temperature; light grey $\mathrm{Cr}_{3} \mathrm{C}_{2}$; dark grey $-\mathrm{Cr}_{7} \mathrm{C}_{3}$.

Table 1. Chemical composition and mechanical properties of $\mathrm{Cr}_{3} \mathrm{C}_{2}$-Ni cermets investigated

\begin{tabular}{c|c|c|c|c}
\hline Grade & $\begin{array}{c}\text { Carbide } \\
\text { content, } \\
\text { wt\% }\end{array}$ & $\begin{array}{c}\text { Density, } \\
\mathrm{g} \mathrm{cm}^{-3}\end{array}$ & $\begin{array}{c}\text { Vickers hardness } \\
\mathrm{HV}\end{array}$ & $\begin{array}{c}\text { Fracture toughness } K_{\mathrm{IC}}, \\
\mathrm{MPa} \mathrm{m}^{0.5}\end{array}$ \\
\hline C1 & 90 & 6.9 & 1490 & 9.5 \\
C2 & 80 & 7.1 & 1368 & 13.8 \\
C3 & 70 & 7.3 & 995 & 18.3 \\
C4 & 60 & 7.5 & 900 & 19
\end{tabular}

The chemical composition and mechanical properties are summarized in Table 1. Carbide particle size was of $3.5-8.0 \mu \mathrm{m}$ for all cermets. Hardness measurements were made on cross-sectioned surfaces using a Vickers indenter and $5 \mathrm{~kg}$ load. The fracture toughness of the materials was measured using the indentation method $\left[{ }^{12}\right]$. The density was measured using the water immersion technique (Archimedes approach).

The erosion tester used in this study was a four-channel centrifugal device that has been described in detail elsewhere $\left[{ }^{9,13}\right]$. To study erosion at elevated temperature, the centrifugal apparatus was put into the heated test chamber (Fig. 2). The test conditions that were chosen for this investigation are given in Table 2. The abrasive used in this work was rounded silica as the most common naturally occurring erodent.

To quantify weight loss during erosion experiments, the specimens were ultrasonically cleaned in acetone and weighed before and after the erosion tests with an accuracy of $0.01 \mathrm{mg}$. Typically, each test was repeated four times and the mass loss averaged. The variation in the measured mass loss was rarely greater than 5\% and the values of the erosion rates obtained for each test were within 5\% 


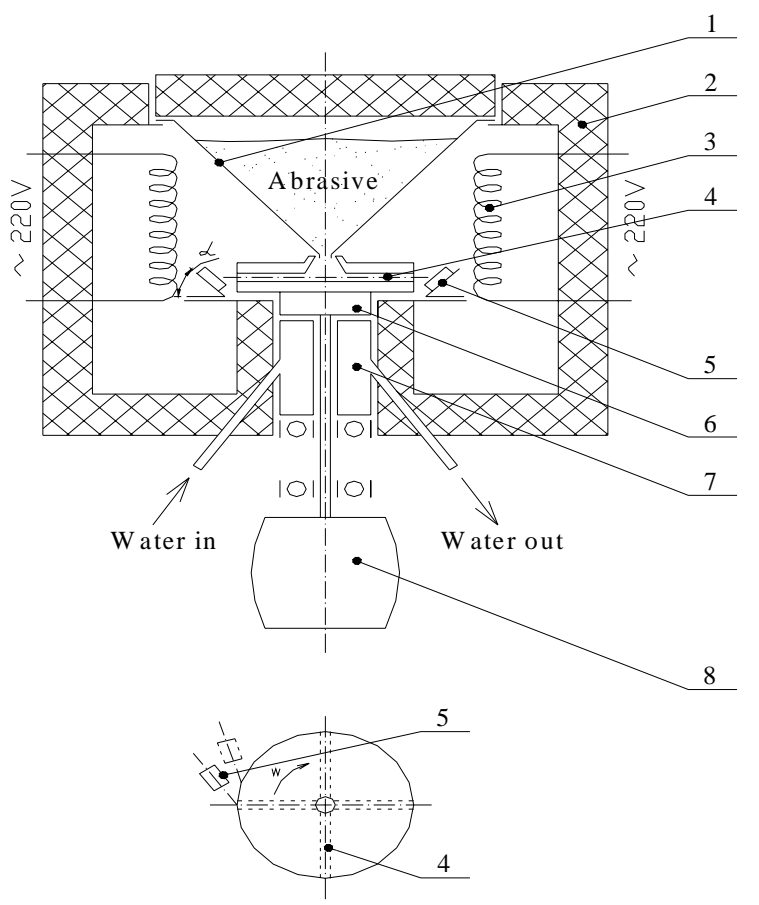

Fig. 2. Schematic of the erosion test apparatus: 1 -abrasive bunker; 2 -isolation; 3 - heating elements; 4 -rotor with channels; 5 -specimen; 6 -system to avoid vibration; 7 - shaft cooling system; 8 - electric motor.

Table 2. Erosion test conditions

Particle velocity
Impact angle
Erodent
Erodent size range
Temperature
Hardness of erodent
Toughness of erodent

Particle velocity

Erodent size range

Hardness of erodent

Toughness of erodent

$$
\begin{aligned}
& 10,20,60,80 \mathrm{~m} / \mathrm{s} \\
& 30,60,75,90^{\circ} \\
& \mathrm{SiO}_{2} \\
& 0.1-0.3 \mathrm{~mm} \\
& 20,300, \text { and } 600^{\circ} \mathrm{C} \\
& 1100 \mathrm{HV} \\
& 1.2 \mathrm{MPa} \mathrm{m}^{0.5}
\end{aligned}
$$

of the mean. The volumetric erosion rate $\left(\mathrm{mm}^{3} / \mathrm{kg}\right)$ was calculated by dividing weight loss rate $(\mathrm{mg} / \mathrm{kg})$ by the density of the material $\left(\mathrm{mg} / \mathrm{mm}^{3}\right)$.

\section{RESULTS AND DISCUSSION}

\subsection{Erosion at room temperature}

Material loss in erosion depends on impingement angle, impact velocity, mass of the abrasive particles (test conditions) and on microstructure of the material $\left[{ }^{12,14}\right]$. Removal of material occurs through the process of micro-plastic deformation or brittle fracture. For ductile materials, the impact of the particles 
causes severe localized plastic strain at the impact site on the surface. Material is removed, when the strain exceeds the material's failure strain. For brittle materials, the force of the impacting particle causes localized cracking at the surface. With subsequent impact events, these cracks propagate and eventually link together, and as a result the material detaches from the surface. As a consequence, the particle impact angle on the surface affects each material in a different manner. Material loss for ductile metals tends to peak at an oblique angle of impact. However, material loss for brittle materials tends to increase with increasing impingement angle with maximum material loss occurring at $90^{\circ}$.

Figure 3a shows the angular dependence of the steady state erosion rate of the materials tested at impact velocity of $60 \mathrm{~ms}^{-1}$ at $20^{\circ} \mathrm{C}$. The $\mathrm{Cr}_{3} \mathrm{C}_{2}$-based composites with low binder content (or with high hardness) such as $\mathrm{C} 1$ and $\mathrm{C} 2$ grades have poorer erosion resistance at high impact angles (the value of erosion rate at 75 and $90^{\circ}$ is almost the same) than at more oblique angles. This is closer to the behaviour of brittle ceramic materials. At impact angle of $90^{\circ}$ the stress is remarkably higher than at impact angle of $30^{\circ}$ and, as a result, wear rates are higher. For comparison, ductile materials exhibit maximum erosion rates at impact angles between 30 and $60^{\circ}$. The $\mathrm{C} 3$ and $\mathrm{C} 4$ grades exhibit a maximum erosion rate between 60 and $75^{\circ}$ that is closer to the behaviour of ductile materials. There are clearly two competing mechanisms of erosion, one responsible for the loss of the softer binder phase $\mathrm{Ni}$ and the other leading to the loss of the brittle $\mathrm{Cr}_{3} \mathrm{C}_{2}$ grains.

Figure $3 \mathrm{~b}$ shows that the general trend is an increasing erosion rate with increasing velocity for all the volume fractions used. As it can be seen from Fig. 3b, the erosion rates of $\mathrm{C} 4$ and $\mathrm{C} 3$ are much (up to 3 times at $80 \mathrm{~m} / \mathrm{s}$ ) higher than those of $\mathrm{C} 2$ or $\mathrm{C} 1$ and the difference in erosion rates of these two groups of materials increases with increasing impact velocity.

If the material hardness exceeds that of the abrasive (grades C1 and C2), the erodent particles can hardly cause plastic flow in a hard target and selective nature of erosion prevails $\left[{ }^{15}\right]$. The degree of elastic penetration and therefore energy, transmitted to a surface, depends on the elasticity modulus and, if the

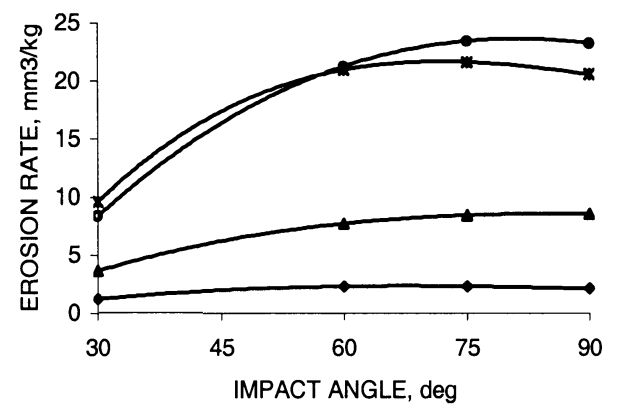

(a)

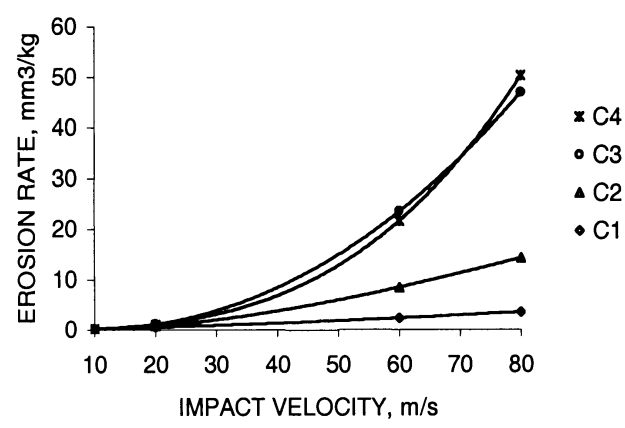

(b)

Fig. 3. Effect of the impact angle at particle velocity of $60 \mathrm{~ms}^{-1}$ (a) and of the impact velocity at collision angle of $75^{\circ}$ (b) on the erosion rate of cermets at room temperature. 

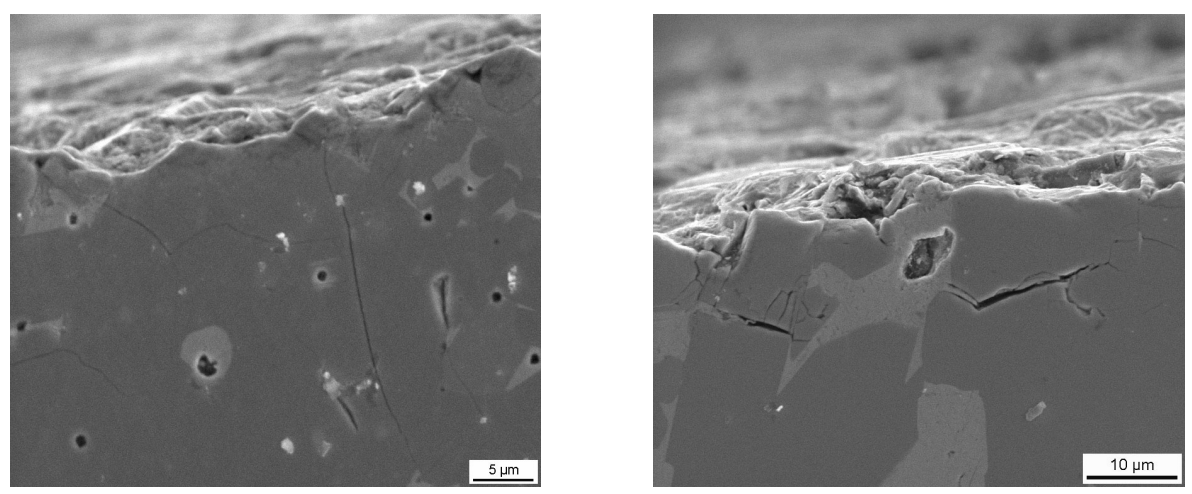

Fig. 4. Hard particles cracking under impact loading.

latter is high, less elastic penetration occurs. Under these conditions the impact of abrasive particles may cause a low-cycle fatigue failure of the carbide matrix and carbide grains. If the hardness of an abrasive exceeds that of the cermet (grades $\mathrm{C} 3$ and $\mathrm{C} 4$ ), the following processes take place: penetration of abrasive into the material surface, microcutting or ploughing, and failure of carbide grains resulting in the detachment of small chips.

Because the $\mathrm{Cr}_{3} \mathrm{C}_{2}$ particles are brittle $\left(K_{\mathrm{IC}}=3-3.5 \mathrm{MPa} \mathrm{m}^{0.5}\right)\left[{ }^{16}\right]$, crack initiation would be expected to occur in them first (Fig. 4). As a result, more of the load is transferred to the surrounding $\mathrm{Ni}$ alloy binder. However, because $\mathrm{Ni}$ is tough $\left(K_{\mathrm{IC}}>100 \mathrm{MPa} \mathrm{m}{ }^{0.5}\right)\left[{ }^{16}\right]$, it deforms plastically forming ligaments, which resist the propagation of the crack.

It is well known that plastic cyclic straining of metals leads to low-cycle fatigue crack extension $\left[{ }^{17}\right]$. In the metal-binder phase, discontinuously filled by hard particles, the rate of crack extension may be reduced by crack bridging or accelerated by other factors, but failure is still dominated by one or few major cracks. It is also true for composites with well-bonded particles that cannot deflect matrix cracks $\left[{ }^{17}\right]$.

\subsection{Erosion at elevated temperatures}

The influence of the temperature on the erosion rates of $\mathrm{Cr}_{3} \mathrm{C}_{2}$-Ni composites tested is shown in Fig. 5. The values of the erosion rate were determined for the impact angle of $75^{\circ}$. Increasing the temperature up to $300^{\circ} \mathrm{C}$, the erosion rate of cermets with low binder content $(\mathrm{C} 1$ and $\mathrm{C} 2)$ remains relatively constant. On the other hand, cermets with high binder content show even better erosion resistance at $300^{\circ} \mathrm{C}$ than at room temperature. This may be a result of the softening of the binder metallic material. For those materials the decreasing of the erosion rate to a minimum value with increasing temperature, followed by an increase in the erosion rate as the test temperature is increased, is not an uncommon phenomenon, particularly at high impingement angles. At $600^{\circ} \mathrm{C}$ all cermets tested have higher erosion rates than at room temperature. 


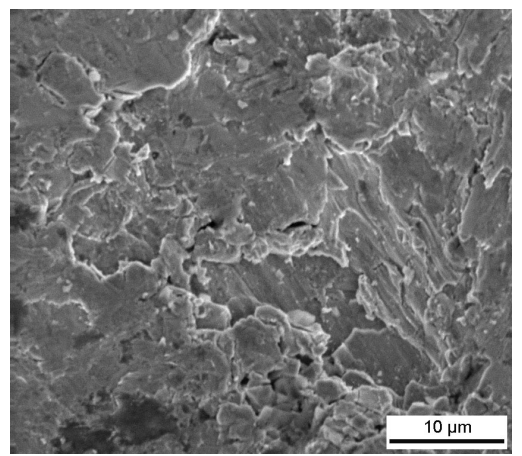

(a)

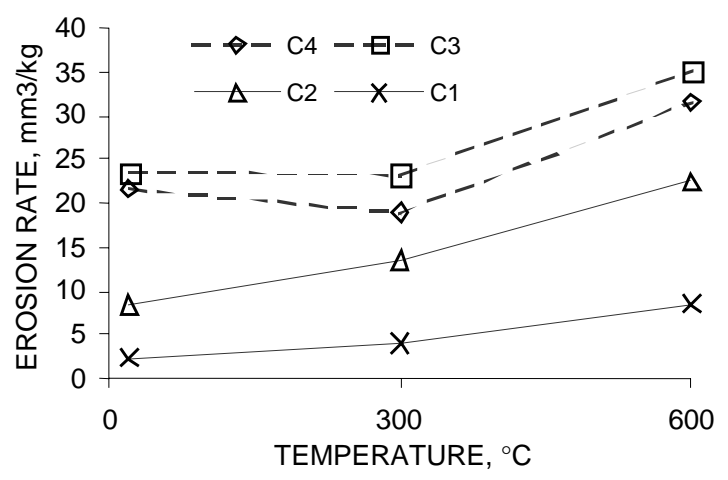

(b)

Fig. 5. Effect of the test temperature on the erosion rate of cermets at impact angle of $75^{\circ}$ : a - SEM micrograph of the eroded surface of $\mathrm{C} 3$ grade at $300^{\circ} \mathrm{C} ; \mathrm{b}$ - erosion rate vs. temperature.

Alman et al. $\left[{ }^{18}\right]$ analysed erosion of WC-Co hard metals. The erosion rate of the WC-6\%Co materials increased steadily with increasing test temperature up to $700^{\circ} \mathrm{C}$. The measured erosion rate at $700^{\circ} \mathrm{C}$ was more than double the rate at room temperature. Tests were attempted also at $900^{\circ} \mathrm{C}$, but oxidation of the cobalt was severe, thereby nullifying the results. Air oxidizes the surface of the specimen very rapidly $\left[{ }^{19}\right]$.

Figure 6a shows the shift of the maximum of the erosion rates to more oblique angles measured at the particle velocity of $60 \mathrm{~ms}^{-1}$. At high temperature all the materials investigated have been more ductile than at room temperature. Figure $6 \mathrm{~b}$ shows the effect of particle velocity on the erosion rate of cermets.

Figure 6 indicates that in case of a high impact angle at high temperature the $\mathrm{C} 4$ cermet performs better than $\mathrm{C} 3$, even though $\mathrm{C} 3$ is harder and contains more carbides. This fact can be explained by evaluation of the mechanisms by which the material is removed from the surface during erosion.

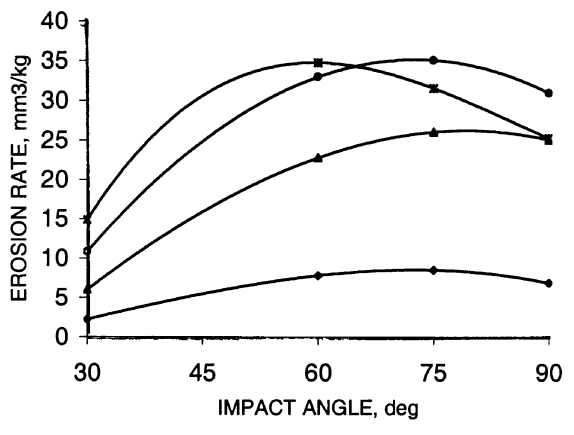

(a)

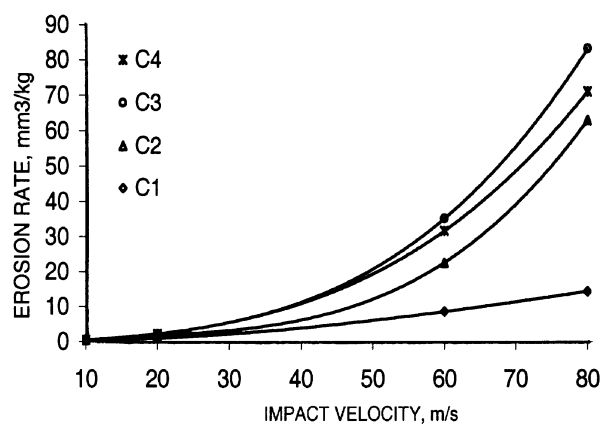

(b)

Fig. 6. Effect of the impact angle (a) and velocity (b) on the erosion rate of cermets at the temperature of $600^{\circ} \mathrm{C}$. 


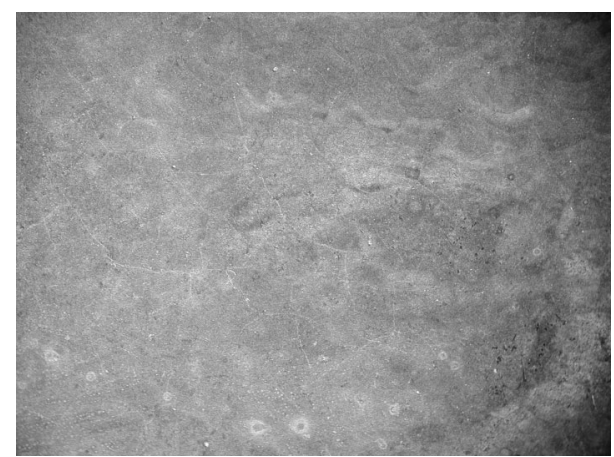

(a)

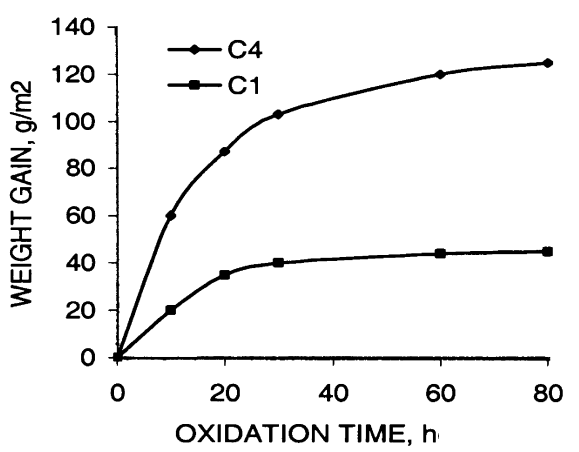

(b)

Fig. 7. Surface oxidation of $\mathrm{C} 1$ grade (a) and weight gain per unit area vs oxidation time (b).

To study $\mathrm{Cr} 3 \mathrm{C} 2-\mathrm{Ni}$ cermets oxidation, tests were carried out using special heated furnace at $\mathrm{T}=1050^{\circ} \mathrm{C}$ in the air atmosphere. The grades $\mathrm{C} 1$ and $\mathrm{C} 4$ were chosen for the study. The weight gain of the samples due to oxidation in air was recorded and is shown in Fig. 7. Owing to the low rate of oxidation, the maximum oxidation time was $80 \mathrm{~h}$.

In an oxidizing environment, the erosion behaviour at elevated temperatures depends on the rate of oxidation and on the thickness, morphology, adherence, and toughness of the oxide layer that forms on the surface of the material during the oxidation process $\left[{ }^{19}\right]$. For materials with a high level of oxidation, the erosion behaviour is controlled by the properties of the oxide layer. These materials cannot be used for applications with erosion processes involved because the oxide layer (film) readily detaches itself from the surface under abrasive impacts $\left[{ }^{19}\right]$. In addition, repeated impacts from the erosion particles constantly expose fresh binder material to the oxidizing environment, exacerbating oxidation and material loss. The oxidation rate of chromium carbide based materials is small enough at high temperatures and cannot affect the erosion rate, thus their erosion resistance at elevated temperatures depends, first of all, on the material tolerance to damage. However, an increase in $\mathrm{Ni}$ content leads to the increase of oxidation rate.

Scanning electron micrograph showing the erosion damage of $\mathrm{C} 1$ is presented in Fig. 8a. The failure mode is axial splitting, chipping, and cracking of the carbide particles. The transgranular crack propagation mode is indicative of the relatively strong interphase bond. In contrast, the surface of $\mathrm{C} 4$ grade appears somewhat different. In this case, material is removed by the detachment of plastically deformed lips of the binder material as well as by transgranular fracture (Fig. 8b). During erosion, debris from the erodent, due to the surface interaction as well as to the fracture of the abrasive particles, accumulates and is fused by the force and generated heat (Fig. 8b); in the case of other grades the fused erodent debris is not apparent.

Other mechanical factors, such as the influence of the temperature on the hardness, on the interfacial strength, and on the fracture resistance (the ability to 


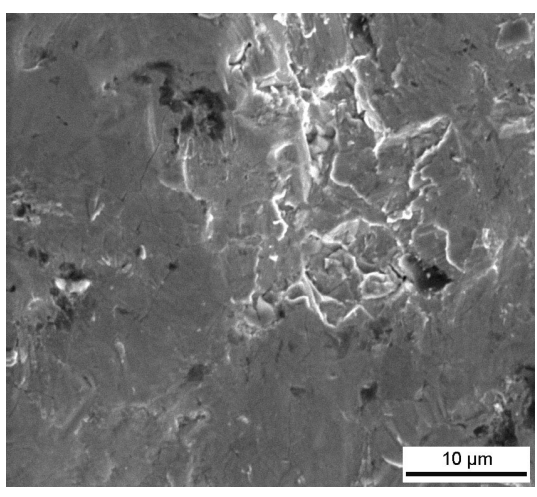

(a)

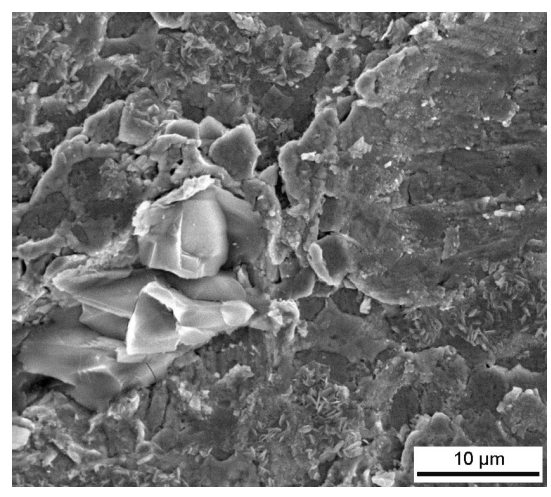

(b)

Fig. 8. Erosion damage at $300{ }^{\circ} \mathrm{C}$ on the surface of the $\mathrm{C} 1$ grade (a), and $\mathrm{C} 4$ grade (b).

absorb energy of repeated impacts) may also contribute to the erosion behaviour of these materials; however, these mechanisms have not been studied in detail to date.

The erosion rate $(E)$ depends on the testing conditions as follows $\left[{ }^{4,11,14,18}\right]$ :

$$
E=k v^{n} f(\alpha)
$$

where $k$ is a coefficient depending on material and erosion properties, $v$ is the particle velocity and $\alpha$ is the impact angle. The empirical relationships of $E$ of chromium carbide based cermets as a function of the particle velocity below the transition velocity at the impact angle of $75^{\circ}$ are the following:

\begin{tabular}{l|l|l}
\hline Grade & $E$, room temperature & \multicolumn{1}{c}{$E, \mathrm{~T}=600^{\circ} \mathrm{C}$} \\
\hline $\mathrm{C} 1$ & $E \propto v^{1.48}\left(R^{2}=0.995\right)$ & $E \propto v^{1.4}\left(R^{2}=0.935\right)$ \\
$\mathrm{C} 2$ & $E \propto v^{2.51}\left(R^{2}=0.988\right)$ & $E \propto v^{2.3}\left(R^{2}=0.99\right)$ \\
$\mathrm{C} 3$ & $E \propto v^{2.72}\left(R^{2}=1\right)$ & $E \propto v^{2.43}\left(R^{2}=0.995\right)$ \\
$\mathrm{C} 4$ & $E \propto v^{2.7}\left(R^{2}=0.999\right)$ & $E \propto v^{2.65}\left(R^{2}=0.995\right)$
\end{tabular}

A value of $n=2$ would be expected considering the kinetic energy of the impacting particle, given by $1 / 2 m v^{2}$. A satisfactory explanation for the deviation of $n$ from 2 has not yet been given in the literature. For more brittle materials with a low binder content, the values of $n$ less than 2 may be ascribed to the inefficiency of lateral crack initiation and propagation due to the fragmentation of the brittle erodents. Also, the lower hardness and toughness of the silica erodent striking cermets are themselves prone to plastic deformation and fracture by impact and the initial kinetic energy is apportioned between the target and the abrasive particles so that less energy is available for erosion. 
Values of $n$ greater than 2 may be caused by target material properties that affect rebound resilience, such as hardness, or by particle variables, such as size, shape and composition or, in the case of a more ductile composite, by embedment of the erodents.

The velocity exponent $n$ decreases with an increase of the erosion test temperature. Covalent bonding in chromium carbides leads to very narrow slip systems that restrict the movement of the dislocations. On the other hand, a very high contact temperature by the collision of two bodies causes the thermal cracks propagation because of the mismatch of the coefficients of thermal expansion for two phases of the target material. The increase in temperature coupled with high stress improves the possibility of dislocations activity that is associated with an inelastic relaxation process. Dislocation motion occurs first in the metallic binder with the beginning of stacking fault reduction due to the increase of the surrounding temperature. Therefore, the dependence of the erosion rate on particle energy or impact velocity becomes smoother.

\section{CONCLUSIONS}

The erosion behaviour of $\mathrm{Cr}_{3} \mathrm{C}_{2}-\mathrm{Ni}$ cermets with low binder content is analogous to that of brittle materials. The erosion rate increases with the increasing particle impact angle, reaching a maximum value at about $90^{\circ}$ for cermets containing less than $30 \mathrm{wt} \%$ of the binder phase. The erosion of chromium carbide based cermets with a high binder content is associated with a combination of the ductile and brittle modes of erosion. The erosion of hard composites (C1-C3 grades) is associated with intergranular spallation and grain crushing.

High temperature erosion behaviour of chromium carbide based composites depends on the content and properties of the metallic binder. The plasticity of all materials tested increased with increasing temperature.

Chromium carbide based materials may be useful for applications involving high temperatures and aggressive environments because of negligible oxidation.

\section{ACKNOWLEDGEMENTS}

The authors would like to thank Dr. J. Pirso for preparing samples for this study and Dr. M. Viljus for making SEM micrographs. This work was supported by the Estonia Science Foundation (grant No. T505, MT).

\section{REFERENCES}

1. Mari, D. and Gonseth, D. A new look at carbide tool life. Wear, 1993, 165, 9-17.

2. Bolognini, S., Feusier, G., Mari, D., and Viatte, T. High temperature mechnical behavior of Ti(C,N)-Mo-Co cermets. Refract. Metals Hard Metals, 1998, 16, 257-268. 
3. Doğan, C. and Hawk, J. Role of composition and microstructure in the abrasive wear of highalumina ceramics. Wear, 1999, 225-229, 1050-1058.

4. Hussainova, I., Pirso, J., and Kübarsepp, J. Mechanical properties and features of erosion of cermets. Wear, 2001, 250, 818-825.

5. Hines, J., Bradt, R. C., and Biggers, J. Grain size and porosity effects on the abrasion wear of ceramics. J. Am. Ceram. Soc., 1995, 78, 881-891.

6. Allman, D., Tylczak, J., and Hawk, J. An assessment of the erosion resistance of iron-aluminide cermets at room and elevated temperatures. Wear, 2002, 329, 602-609.

7. Dogan, Ö., Hawk, J., Tylczak, J., and Wilson, R. Wear of titanium carbide reinforced metal matrix composites. Wear, 1999, 225, 758-769.

8. Stack, M. and Pena, D. Solid particle erosion of Ni-Cr/WC metal matrix composites at elevated temperatures. Wear, 1997, 203, 489-497.

9. Hussainova, I. Some aspects of solid particle erosion of cermets. Tribol. Int., 2001, 34, 89-93.

10. Sundararajan, G. and Roy, M. Solid particle erosion behaviour of metallic materials at room and elevated temperatures. Tribol. Int., 1997, 30, 339-359.

11. Hussainova, I., Pirso, J., and Viljus, M. Processing and tribological properties of chromium carbide based cermets. In Advances in Powder Metallurgy and Particulate Materials: Hard Metals/ Refractory metals/ Composite, Part 6. Metal Powder Industry Publications, Princeton, 2002, 8-17.

12. Evans, A. and Charles, E. Wear mechanisms in ceramics. J. Am. Ceram. Soc., 1979, 62, 371382.

13. Söderberg, S., Hogmark, U., Engman, H., and Swahn, H. Erosion classification of materials using a centrifugal erosion tester. Tribol. Int., 1981, 5, 333-343.

14. Hutchings, I. Tribology: Friction and Wear of Engineering Materials. CRS Press, FL, Cambridge, 1992.

15. Reshetnyak, H. and Kübarsepp, J. Mechanical properties of hard metals and their erosive wear resistance. Wear, 1994, 177, 185-193.

16. Kenneth, J. and Brooks, J. Hardmetals and Other Hard Metals. Int. Carbide Data, ASM International, USA, 1992.

17. Dvorak, G. Composite materials: inelastic behavior, damage, fatigue and fracture. Int. J. Solids Struct., 2000, 37, 155-170.

18. Alman, D. E., Tylczak, J. H., Hawk, J., and Hebster, M. Elevated temperature erosion of cermets. Mater. Sci. Eng., 1999, A261, 245-251.

19. Basu, S. and Sarin, V. Oxidation behavior of WC-Co. Mat. Sci. Eng., 1996, A209, 206-212.

\section{Kroomkarbiidkermiste kõrgtemperatuurne kulumine}

\section{Irina Hussainova ja Maksim Antonov}

Kroomkarbiidi baasil komposiitmaterjalide head termomehaanilised omadused, nagu väike tihedus ja keemiline stabiilsus kuni temperatuurini $1300^{\circ} \mathrm{C}$, on eelduseks nende kasutamisel kulumiskindlate materjalidena eelkõige kõrgel temperatuuril. Käesoleva töö eesmärk oli uurida $\mathrm{Cr}_{3} \mathrm{C}_{2}-\mathrm{Ni}$ kermiste käitumist abrasiiverosioonil temperatuuril $300 \mathrm{ja} 600^{\circ} \mathrm{C}$. Uuriti materjali kulumist abrasiivi (kvartsliiva) osakeste erinevate langemisnurkade puhul ning selgitati metallokeraamiliste komposiitide purunemismehhanismi sõltuvus nende mikrostruktuurist ja katsetingimustest. Uuriti $\mathrm{ka} \mathrm{Cr}_{3} \mathrm{C}_{2}$-Ni materjalide kõrgtemperatuurset oksüdatsiooni, et kindlaks teha nende materjalide kasutuseelised võrreldes traditsiooniliste kõvasulamitega. 